\title{
Faktor Pemberian Nutrisi Masa Golden Age dengan Kejadian Stunting pada Balita di Negara Berkembang
}

\author{
Meri Anggryni', Wiwi Mardiah2, Yanti Hermayanti ${ }^{3}$, Windy Rakhmawati ${ }^{4}$, Gusgus Graha \\ Ramdhanie $^{5}$, Henny Suzana Mediani ${ }^{6 \bowtie}$ \\ Keperawatan Anak, Universitas Padjadjaran
}

DOI: $10.31004 /$ obsesi.v5i2.967

\begin{abstract}
Abstrak
Stunting merupakan masalah kesehatan utama yang dapat menghambat masa depan bangsa. Hal tersebut terindikasi dari tingginya prevalensi stunting serta dampak buruk yang ditimbulkan. Tujuan review ini adalah mengidentifikasi faktor-faktor pemberian nutrisi pada masa golden age yang menyebabkan kejadian stunting pada balita di negara berkembang termasuk Indonesia. Pencarian secara sistematik dari literature 2015-2020 menggunakan Google Scholar, Proquest, Pubmed, Taylor and Francis, Plos One. Kata kunci pencarian: pemberian nutrisi, masa golden age, balita, stunting, negara berkembang. Peneliti memperoleh 28 artikel final yang dianalisis sesuai kriteria. Hasil menggambarkan faktor penyebab kejadian stunting terjadi sejak kehamilan akibat kekurangan nutrisi pada masa tersebut, inisiasi menyusui dini kurang dari 1 jam kelahiran maupun tidak sama sekali, pemberian ASI terhenti $<6$ bulan dan frekuensi menyusu tidak cukup, serta pemberian makanan pendamping ASI $<6$ maupun $>12$ bulan, dan makanan yang diberikan tidak bervariasi dengan frekuensi dan tekstur yang tidak sesuai usia.
\end{abstract}

Kata Kunci: balita; indonesia; masa golden age; negara berkembang; pemberian nutrisi; stunting

\begin{abstract}
Abstrak
Stunting is a major health problem that can hinder the future of the nation. This is indicated by prevalence of stunting and its adverse effects. The purpose of this review is to identify the nutritional factors during the golden age that cause stunting in children under five in developing countries, including Indonesia. Systematic search of the 2015-2020 literature using Google Scholar, Proquest, Pubmed, Taylor and Francis, Plos One. Keyword search: nutrition, golden age, toddler, stunting, developing countries. The researcher obtained 28 final articles which were analyzed according to the criteria. The results describe the factors that cause stunting occurring since pregnancy due to nutritional deficiencies at that time, early initiation of breastfeeding less than 1 hour of birth or not, stopping breastfeeding $<6$ months and insufficient breastfeeding frequency, complementary feeding $<6$ or $>12$ months, and the food given did not vary with frequency and texture that was not age-appropriate Keywords: developing countries; golden age; nutrition practice; stunting; toddlers.
\end{abstract}

Copyright (c) 2021 Meri Anggryni, Wiwi Mardiah, Yanti Hermayanti,Windy Rakhmawati, Gusgus Graha Ramdhanie, Henny Suzana Mediani

$\triangle$ Corresponding author:

Email Address: henny.mediani@unpad.ac.id (Bandung, Indonesia)

Received 14 December 2020, Accepted 31 December 2020, Published 9 Januari 2021 


\section{PENDAHULUAN}

Stunting merupakan masalah kesehatan utama yang dapat menghambat masa depan bangsa. Hal tersebut diindikasikan berdasarkan standar WHO, yakni 20\% atau seperlima dari jumlah total balita. Berdasarkan prevalensi secara global, terdapat sebanyak 22,9\% atau 154,8 juta anak balita dengan kasus tersebut dan menjadi 22,2\% atau sekitar 150,8 juta balita di tahun 2017. Kondisi tersebut terpusat di negara miskin 35,2\% dan negara berkembang 22,4\%, yang tersebar di Asia dengan prevalensi 56\% dan Afrika 39\%. Kondisi demikian kebanyakan ditemukan di negara berkembang dari kedua benua, dimana dari 88 negara dengan kasus tertinggi, empat diataranya merupakan negara berkembang, yakni India $48 \%$, Pakistan $42 \%$, Nigeria 41\% dan Indonesia 37\% (tahun 2007 [36,8\%], tahun 2010[35,6\%], tahun 2013 [37,2\%] dan tahun 2018 [30,8\%]) (United Nations Children's Fund [UNICEF], World Health Organitation [WHO], World Bank Group [WBG], 2018; Riset kesehatan dasar [Riskesdas], 2013-2018). Kondisi ini tidak dapat diabaikan. Oleh sebab itu, untuk meningkatkan kesadaran pentingnya penanganan masalah ini, masyarakat dan pemerintah perlu mengetahui dampak yang ditimbulkan kondisi tersebut.

Selain prevalensi tersebut, dampak akibat stunting juga dapat menghambat masa depan bangsa. Pada dampak jangka pendek, anak dapat mengalami gangguan otak, kecerdasan, gangguan pertumbuhan fisik, dan gangguan metabolisme dalam tubuh. Sedangkan dalam jangka panjang, dapat menurunnya kemampuan kognitif dan prestasi belajar, menurunnya kekebalan tubuh sehingga mudah sakit, risiko tinggi munculnya penyakit diabetes, kegemukan, penyakit jantung dan pembuluh darah, kanker, stroke dan disabilitas pada usia tua, meningkatkan risiko penyakit dan kematian perinatal-neonatal, serta kualitas kerja yang tidak kompetitif dan akan menghasilkan rendahnya kualitas sumber daya manusia (SDM) yang berakibat pada rendahnya produktifitas ekonomi. (Apriluana \& Fikawati, 2018; Anugraheni \& Kartasurya, 2012; Hossain et al., 2017; Kemenkes, 2018; Dewey \& Begum, 2011; De Onis et al., 2012; Mediani, 2020; Kemenkes RI, 2016; Izwardy, 2019, Helmyati, 2019; Badan Perencanaan Pembangunan Nasional [Bapennas], 2018). Sehingga, diperlukan upaya penanganan yang serius dari berbagai pihak, untuk dapat mencegah dan mengurangi dampak yang dialami balita dengan kondisi tersebut.

Sampai saat ini, pemerintah masih berupaya dalam penurunan stunting. Dimulai dari penetapan tujuan pembangunan oleh Perserikatan Bangsa-Bangsa (PBB) yang dikenal dengan The Sustainable Development Goals (SDG's) yang salah satu tujuannya berupa penurunan stunting dan wasting pada balita di seluruh dunia, serta merupakan target internasional tahun 2030 (United Nation Development Programme [UNDP], 2018) Sebagai bentuk realisasi, WHO (2014) dan UNICEF (2013) membuat kerangka kerja yang mengelompokkan faktor-faktor risiko kedalam tiga kelompok yakni; (1) faktor distal meliputi, politik dan ekonomi, pelayanan kesehatan, pendidikan, sosial budaya, sistem pertanian dan makanan, serta air, sanitasi dan lingkungan; (2) intermediate factors yaitu, faktor rumah tangga yang meliputi, jumlah dan kualitas makanan yang tidak adekuat, sumber daya yang rendah, ukuran dan struktur keluarga, praktik yang tidak memadai, perawatan kesehatan yang tidak memadai, layanan air dan sanitasi yang tidak memadai, (3) faktor proksimal meliputi pemberian nutrisi, faktor ibu dan lingkungan, faktor anak, dan faktor infeksi. Untuk menyelesaikan permasalahan tersebut, dapat dilakukan melalui faktor-faktor risiko langsung penyebab stunting. Namun untuk itu, dibutuhkan intervensi yang terstruktur untuk merealisasikan upaya tersebut.

Sebagai bentuk keseriusan dalam pencegahan dan penanganan stunting, pemerintah membentuk dua intervensi gizi, yakni intervensi gizi spesifik dan intervensi gizi sensitif (TNP2K, 2017; Trihono, 2015). Intervensi gizi spesifik ditunjukkan kepada ibu hamil, ibu menyusui dan anak usia 0-23 bulan. Intervensi ini merujuk pada intervensi yang langsung menangani faktor penentu gizi janin serta gizi anak, mulai dari pemenuhan nutrisi selama kehamilan hingga pemberian makanan tambahan (International Food Policy Research Sience Review [IFPRI], 2016). Sedangkan, intervensi gizi sensitif ditunjukkan melalui berbagai kegiatan pembangunan di luar sektor kesehatan. Sehingga, perawat sebagai ujung tombok 
kesehatan dapat membantu percepatan penanganan kondisi tersebut dengan menyukseskan program intervensi gizi spesifik khususnya pemberian nutrisi pada masa 1000 hari pertama kehidupan (Masa golden age). Namun untuk itu, perawat perlu mengetahui faktor-faktor pemberian nutrisi pada masa golden age secara komprehensif.

Berdasarkan literatur, stunting dapat terjadi sejak 1000 hari pertama kehidupan, mulai dari 270 hari janin didalam kandungan sampai 720 hari pertama kelahiran ( Schmidt, 2014; Ikatan Dokter Anak Indonesia [IDAI], 2015). Pada masa kehamilan, pemberian nutrisi pada janin bergantung sepenuhnya pada kecukupan gizi ibu hamil. Kondisi tersebut dinilai dari status gizi ibu hamil, yang diukur menggunakan lingkar lengan atas (LILA). Pengukuran tersebut bertujuan untuk mengetahui apakah ibu mengalami kekurangan gizi, khususnya kekurangan energi kronis (Ferial, 2012). Menurut data Riset Kesehatan Dasar (RISKESDAS) Indonesia tahun 2013-2018, terdapat 24,2\% Ibu hamil di tahun 2013 mengalami kekurangan energi kronis dan menjadi 17,3\% pada 2018. Hal ini cukup mengkhawatirkan, mengingat KEK pada ibu hamil dapat mengakibatkan janin didalam kandungan mengalami kekurangan asupan nutrisi diawal kehidupan yang berdampak pada pertumbuhan janin.

Pertumbuhan janin didalam kandungan melalui tiga tahapan yang terbagi kedalam tiga trimester. Pada trimester pertama, pertumbuhan janin masih lambat, peningkatan kebutuhan zat gizi masih relatif kecil. Pada tahap ini, ibu hamil memasuki masa anabolisme yaitu masa untuk menyimpan zat gizi sebanyak-banyaknya dari makanan yang dikonsumsi setiap hari untuk cadangan trimester berikutnya (Damayanti et al, 2017; Kristiyanasari, 2010). Untuk itu, penting memperhatikan kandungan makanan yang dikonsumsi ibu selama fase ini. Demikian pula pada trimester kedua. Pada tahap ini, janin mulai tumbuh pesat dibandingkan dengan trimester sebelumnya. Kecepatan pertumbuhan mencapai 10 gram per hari, susunan saraf otak berkembang sampai $90 \%$, lengan, tangan, kaki, jari dan telinga mulai terbentuk, denyut jantung janin mulai terdengar, serta penyimpanan lemak sebagai cadangan pembentuk Air Susu Ibu (ASI) dimulai (Marmi, 2013; Damayanti et al, 2017; Kristiyanasari, 2010; Almatsier, 2011). Pada tahapan ini, terjadi peningkatan kebutuhan energi untuk metabolisme tubuh janin. Sehingga, ibu dianjurkan untuk meningkatkan asupan gizi dibandingkan sebelumnya.

Begitupun pada trimester ketiga. Pada masa ini, kebutuhan asupan nutrisi dari simpanan cadangan energi ibu selama tahap sebelumnya semakin meningkat. Karena pada tahap ini, janin tumbuh menjadi dua kali panjang sebelumnya dan berat badan bertambah kurang lebih lima kali dari berat semula (Damayanti et al, 2017; Kristiyanasari, 2010). Untuk itu, status gizi ibu di trimester sebelumnya harus baik, dan didukung dengan memaksimalkan kebutuhan asupan gizi di trimester ini.

Setelah melalui ketiga tahapan tersebut, janin akan keluar dari rahim ibu melalui proses persalinan. Sesaat setelah proses tersebut, bayi harus segera diberikan nutrisi untuk memenuhi kebutuhan tubuhnya. Proses pemberian nutrisi tersebut diberikan melalui pemberian Inisiasi Menyusui Dini (IMD), yakni pemberian air susu ibu kepada bayi segera dalam waktu 30 menit setelah lahir. Dalam proses tersebut, bayi akan melakukan gerakan menghisap yang dapat merangsang hormon oksitoksin mengencangkan otot halus pada sekitar alveoli untuk memeras ASI menuju saluran susu (IDAI, 2015). Untuk itu, pemberian inisiasi menyusui dini harus diberikan dan tidak boleh tertunda.

Berdasarkan data Riskesdas tahun 2013-2018, pemberian nutrisi segera setelah lahir pada anak di Indonesia cukup mengkhawatirkan. Hal ini terlihat dari rata-rata bayi yang memperoleh inisiasi menyusui dini sesuai rekomendasi WHO yakni $\geq 1$ jam setelah lahir, hanya sebanyak 15,9\%. Padahal, dengan pemberian IMD bayi dapat memperoleh kolestrum, yakni ASI yang kaya akan daya tahan tubuh, antibodi terhadap infeksi, pertumbuhan usus dan asupan gizi yang penting untuk pertumbuhan anak (Permadi et al., 2017). Serta, dapat menstimulus ASI keluar dengan baik, dan membantu keberhasilan pemberian ASI eksklusif (Apriluana \& Fikawati, 2018) 
Memasuki usia 0-6 bulan, pemberian nutrisi sebaiknya dilakukan dengan pemberian ASI eksklusif. Indikasi eksklusif jika bayi hanya diberikan ASI tanpa suplementasi makanan maupun minuman lain, baik berupa air putih, jus ataupun susu, kecuali obat, vitamin dan mineral (Millenium challenge count [MAC] Indonesia, 2013; IDAI, 2015). Berdasarkan literature, pemberian ASI eksklusif dapat memenuhi kebutuhan asupan gizi bayi selama 6 bulan pertama, sampai mencapai tumbuh kembang yang optimal (IDAI, 2015). Sehingga, pemenuhan nutrisi pada masa ini cukup hanya dengan ASI eksklusif. Namun, hal tersebut sepertinya belum dianggap penting oleh sebagian besar masyarakat. Hal ini terlihat dari data Riskesdas tahun 2013-2018. Dimana, hanya 21,2\% bayi pada tahun 2013 yang memperoleh ASI eksklusif, dan pada tahun 2018 menjadi 37,3\%. Kondisi tersebut sangat memprihatinkan dan merugikan bayi dan keluarga. Untuk itu, diperlukan upaya dalam meningkatkan hal tersebut.

Selanjutnya, pemberian nutrisi dengan ASI pada anak usia 6-12 hanya mampu memenuhi kebutuhan gizi bayi sebanyak $60 \%$, dan $40 \%$ nya harus dipenuhi dengan makanan pendamping ASI (MP-ASI). Makanan tersebut membantu bayi memperoleh energi yang berguna untuk pertumbuhan dan perkembangannya (Mufida, 2015). Pemberian makanan tambahan harus dilakukan dengan sesuai ketentuan yang ada, jika pemberian tidak tepat anak dapat mengalami kekurangan nutrisi. Pentingnya hal tersebut, sepertinya belum diperhatikan oleh masyarakat di negara berkembang. Hal ini terlihat dari hasil Riskesdas tahun 2013, terdapat 79,8\% anak di Indonesia diberikan makanan tambahan terlalu dini pada usia 0-5 bulan, dan menjadi 42,3\% pada tahun 2018. Hal ini tidak dapat dibiarkan, karena dapat mengakibatkan anak kekurangan asupan gizi pada anak di usia ini, yang dapat menimbulkan gangguan kesehatan dimasa depan. Untuk itu, pemberian makanan harus dilakukan tepat waktu dan diberikan dalam jumlah cukup sesuai kebutuhan anak.

Berdasarkan data pemberian nutrisi tersebut, diketahui pentingnya pemberian nutrisi di tiap tumbuh kembang anak selama masa golden age. Serta, rendahnya pemberian nutrisi pada masa golden age di Indonesia dan Negara Berkembang. Hal ini dapat menjadi indikasi tingginya prevalensi kejadian stunting pada balita di negara tersebut. Namun untuk dapat memastikan hal tersebut, dibutuhkan penelitian secara komprehensif pada faktor-faktor pemberian nutrisi dengan kejadian stunting pada balita. Penelitian tentang pemberian nutrisi yang telah dilakukan sejauh ini berupa pemberian nutrisi pada masa tertentu atau terpisah, yakni pemberian nutrisi pada ibu hamil saja, pemberian IMD sampai pemberian ASI eksklusif, pemberian ASI eksklusif dan pemberian MP-ASI, atau pemberian IMD sampai pemberian MP-ASI Kismul et al., (2017); Fitri \& Ernita, (2019); Mediani, (2020); Nadiyah, Briawan dan Martianto, (2014). Sedangkan untuk penelitian faktor-faktor pemberian nutrisi pada masa golden age dengan kejadian stunting pada balita di Indonesia dan negara berkembang secara sistematik review belum pernah dilakukan. Untuk itu, peneliti merasa penelitian sistematik review penting untuk dilakukan, guna mengetahui faktor-faktor pemberian nutrisi dengan kejadian stunting pada balita di Indonesia dan negara berkembang secara komprehensif sehingga diperoleh upaya pencegahan dan penanganan dampak stunting yang aplikatif dan efektif.

\section{METODOLOGI}

Merupakan sebuah penelitian sistematik review, menggunakan The Centre for Review and Dissemination and the Joanna Briggs Institute (JBI) Guideline sebagai panduan dalam menganalisa kualitas artikel. Penelusuran menggunakan Google Scholar, Proquest, Pubmed, Taylor and Francis, dan Plos One dengan kata kunci“ nutrition practice, golden age, child under five year of age, stunting. Kriteria seleksi mengikuti format PEO. Population: Ibu dengan anak stunting usia 0-59 bulan. Exposure: pemberian nutrisi pada masa golden age. Outcome: Stunting. Penelusuran dilakukan pada artikel yang diteliti tahun 2015-2020 di negara berkembang termasuk Indonesia. 
Alur penyeleksian menggunakan PRISMA, sebanyak 28 artikel yang memenuhi kriteria kelayakan dianalisis secara desktiptif melalui naratif sintesis dalam mensintesis hasil artikel yang diperoleh. Artikel diperoleh dari berbagai negara yang termasuk kedalam negara berkembang yakni 17 artikel dari Indonesia, 1 artikel dari Kamboja, 2 artikel dari India dan Pakistan, 1 artikel dari Thailand, 1 artikel dari Cina, 1 artikel dari Urganda, dan 1 artikel dari Armenia, serta 4 artikel dari Ethiopia. Artikel tersebut diperoleh dari jurnal Plos One ( 3 artikel), dan dari database Pubmed (4 artikel), Proquest ( 3 artikel), dan Taylor and Francis (1 artikel), serta diperoleh juga dari search engine Google Schoolar (17 artikel). Untuk artikel penelitian yang paling banyak melibatkan responden adalah penelitian yang dilakukan Cetthakrikul et al., (2018) di Thailand dengan 7018 responden anak diatas 12 bulan, dan responden paling sedikit sebanyak 40 responden dalam penelitian Prabandari et al., (2017)di Indonesia. Lebih jelasnya dapat dilihat pada gambar 1 .

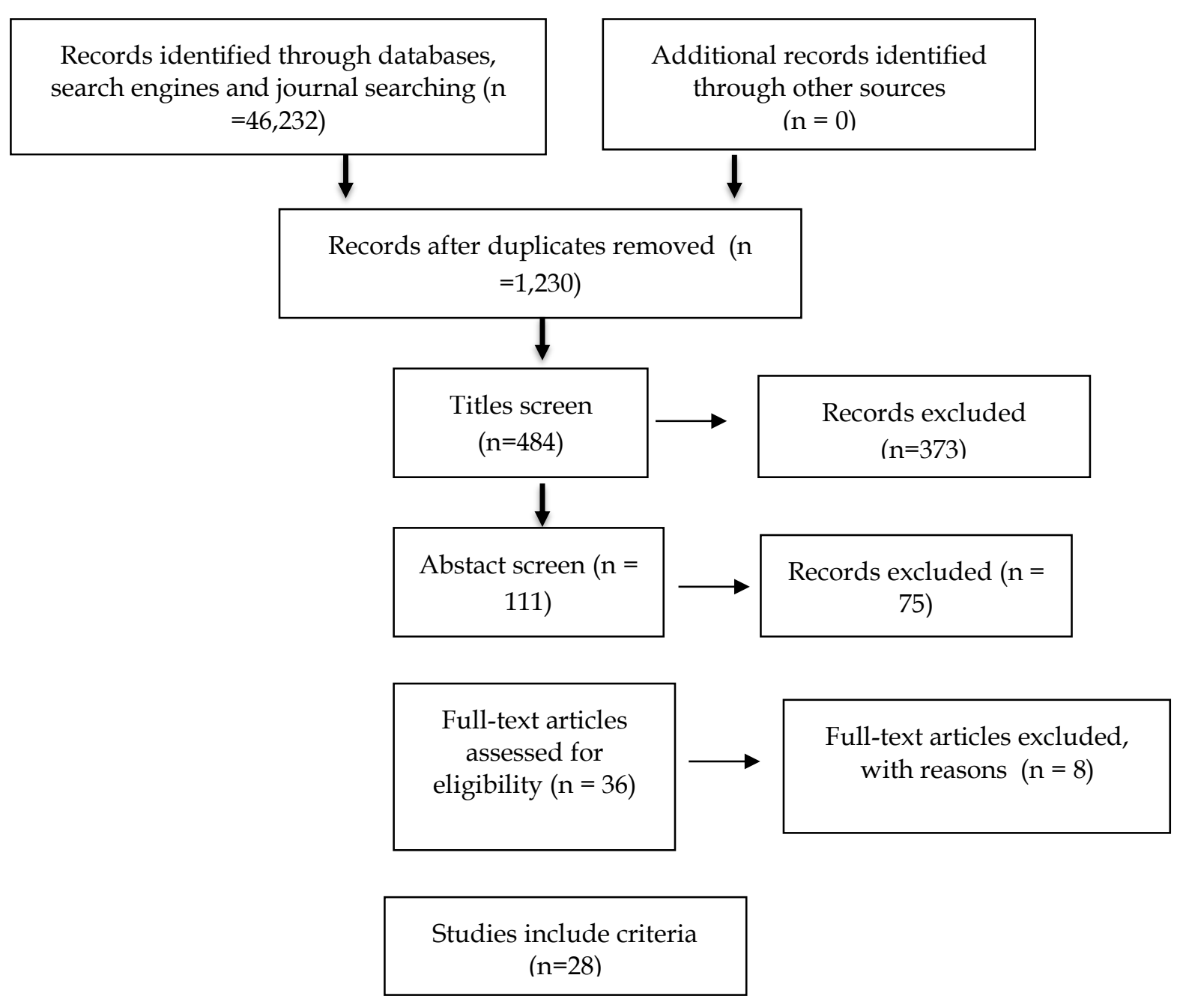

Bagan 1 Alur Penelitian Melalui Proses Seleksi

\section{HASIL DAN PEMBAHASAN}

\section{Faktor Status Gizi Ibu hamil}

Status gizi ibu hamil menjadi tolak ukur kecukupan gizi janin selama didalam kandungan. Hal ini dikarenakan, pemenuhan nutrisi janin selama 270 hari didalam kandungan bergantung penuh pada asupan gizi ibu. Oleh karena itu, ibu harus mampu memenuhi kebutuhan nutrisi selama kehamilan demi tercapainya tumbuh kembang janin yang optimal. Hal tersebut, sesuai dengan hasil review dari penelitian Som et al., (2018), menunjukkan praktik pemenuhan makan pada ibu hamil yang tidak memenuhi standar dan tidak meningkatkan asupan makan selama kehamilan menjadi penyebab stunting di kamboja. 
Hasil tersebut sejalan dengan Situmeang et al., (2020); Alfarisi et al., (2019) dimana terdapat hubungan signifikan antara asupan energi dan asupan protein dengan kejadian stunting di Indonesia $(\mathrm{OR}=0,215 ; \mathrm{OR}=0,354)$, dan apabila ibu mengalami kekurangan energi kronis selama kehamilan akan melahirkan anak dengan risiko 2,2 kali lebih besar mengalami stunting.

Berdasarkan literatur, pemenuhan nutrisi yang direkomendasikan pada ibu hamil dengan berat badan normal adalah mengkonsumsi 1800 kalori pada trimester pertama, 2200 kalori pada trimester kedua, dan 2400 kalori pada trimester ketiga. Serta diperlukan penambahan energi sebanyak 150 kalori dan protein 17 gr di trimester pertama. Pada trimester kedua penambahan energi meningkat menjadi 300 kalori, protein 17 gr pada trimester kedua dan Fe 9 mg. Sedangkan pada trimester ketiga penambahan kebutuhan energi masih sama yakni 300 kalori, protein 17gr, dan peningkatan Fe $13 \mathrm{mg}$. Serta dianjurkan mengkonsumsi asam folat $600 \mathrm{mcg}$, Vitamin B12 +0,2 ug, Ca $+150 \mathrm{mg}$, dan serat $>25$ gr per hari selama kehamilan (Damayanti et al., 2017). Apabila hal tersebut tidak terpenuhi selama kehamilan, ibu dapat mengalami kekurangan asupan gizi yang apabila dibiarkan dapat mengakibatkan janin didalam kandungan lahir dengan manifestasi tubuh stunting.

Penelitian terkait pemenuhan nutrisi janin dilakukan oleh Dhaded et al., (2020) Penelitian tersebut dilakukan pada komunitas miskin sumber daya di India dan Pakistan dengan memberikan suplemen zat besi-folat pada wanita usia subur dan ibu hamil pada trimester pertama. Hasil penelitian menunjukkan pemenuhan nutrisi prakonsepsi (3 bulan sebelum konsepsi) dan pada trimester pertama dikaitkan dengan penurunan stunting sebanyak $44 \%$. Hasil tersebut cukup rendah mengingat pemberian suplemen telah dilakukan 3 bulan sebelum konsepsi. Hal tersebut bisa saja terjadi karena rendahnya kemampuan ibu memperoleh makanan yang cukup gizi akibat keterbatasan ekonomi dan sumber daya. Sehingga, kebutuhan nutrisi janin hanya diperoleh dari suplemen zat besi-folat yang diperoleh selama penelitian berlangsung. Akibatnya, hanya $44 \%$ ibu yang diberikan suplemen zat besi-folat mulai dari 3 bulan prakonsepsi sampai trimester pertama yang melahirkan anak tanpa stunting, dan 56\% lainnya memiliki anak stunting.

Pada penelitian yang sama, Dhaded et al., (2020) menemukan bahwa pertumbuhan janin dapat dicapai dengan peningkatan asupan energi, protein, dan nutrisi mikro dari sebelum dimulainya trimester kedua kehamilan tanpa memerlukan intervensi lain ( $p<0,005$ dan $p<0,001$ ). Hal tersebut sesuai dengan rekomendasi Damayanti et al., (2017) dimana pada trimester kedua diperlukan penambahan energi sebanyak 300 kalori, protein 17 gr, Fe 9 mg. Hal ini dikarenakan, pada trimester kedua janin akan mengalami pertumbuhan yang dapat mencapai 10 gram/hari, tubuh janin mulai terbentuk satu demi satu. Pada masa ini, tubuh ibu mulai menyimpan lemak dan zat gizi lainnya untuk cadangan pembentukan ASI dan mengakibatkan kebutuhan nutrisi janin semakin meningkat. Oleh karena itu, penting bagi ibu untuk meningkatkan asupan gizi sesuai kebutuhan dan tahapan kehamilan.

Penelitian lainnya oleh Prabandari et al., (2017) di Indonesian, hasil penelitian menunjukkan tidak ada berhubungan riwayat KEK selalam trimester 3 yang dialami ibu dengan status gizi bayi (Indeks $\mathrm{BB} / \mathrm{U}, \mathrm{PB} / \mathrm{U}$ dan $\mathrm{BB} / \mathrm{PB})(\mathrm{p}>0,05)$. Penelitian ini, hanya mengkaji riwayat KEK pada ibu hamil selama trimester 3, sedangkan riwayat di trimester sebelumnya tidak dikaji. Padahal, status gizi ibu hamil setiap trimester saling mempengaruhi. Sebelum memasuki trimester baru, tubuh ibu akan menyimpan cadangan energi untuk digunakan pada trimester selanjutnya. Sehingga, apabila ibu mengalami KEK pada trimester sebelumnya akan mengakibatkan ibu beresiko mengalami KEK di trimester selanjutnya, terlebih apabila kondisi tersebut tidak segera dikaji dan diperbaiki maka akan mengakibatkan ketidak cukupan energi yang penting untuk metabolisme dan pertumbuhan janin didalam kandungan. Dimana pada trimester ketiga, janin tumbuh menjadi dua kali panjang sebelumnya dan berat badan yang bertambah kurang lebih lima kali dari berat semula (Damayanti et al, 2017; Kristiyanasari, 2010). Oleh sebab itu, kekurangan energi kronis selama 
trimester tiga akan sangat berpengaruh dengan status gizi bayi terutama (PB/U) dan dapat mengakibatkan anak mengalami stunting.

\section{Faktor Pemberian IMD}

Setelah melalui 270 hari didalam kandungan, janin akan keluar dari rahim ibu melalui proses persalinan. Sesaat setelah proses tersebut, bayi harus segera diberikan nutrisi untuk memenuhi kebutuhan tubuh bayi yang diberikan melalui IMD. Pemberian yang dilakukan sedini mungkin, membantu bayi mendapatkan kolostrum yakni baik untuk daya tahan tubuh dan asupan gizi, sehingga anak terhindar dari kejadian stunting. Menurut

Angelina, Perdana dan Humairoh (2018) menunjukkan pemberian inisiasi menyusui dini pada balita usia 6-23 bulan berhubungan dengan kejadian stunting $(\mathrm{p}=0,010)$ dan $(\mathrm{OR} 3,308)$ yang artinya anak tidak diberikan inisiasi menyusui dini akan berisiko 3,308 kali mengalami stunting dibandingkan anak yang diberi inisiasi menyusui dini. Begitu pula, Sentana, dan Hasan (2018) penelitian dengan OR sebesar 8,157 Demikian pula, Batiro et al., (2017) di Ethiopia Selatan yang menunjukkan pemberian inisiasi menyusui dini yang terlambat atau setelah satu jam kelahiran merupakan faktor determinan stunting dengan OR=5,16.

Penelitian berbeda, Ahmad et al., (2018) di kota Aceh Indonesia yang menunjukkan inisiasi menyusui dini tidak berkaitan dengan kejadian stunting $(0,530)$. Meskipun demikian, pada penelitian Ahmad et al., (2018) proporsi anak yang diberikan IMD namun tetap mengalami stunting sebanyak $47(26,2 \%)$ dan anak yang tidak diberikan IMD dan mengalami stunting sebanyak $62(29,1 \%)$. Hal ini menunjukkan, meskipun hasil analisa data menyatakan tidak ada hubungan IMD dengan kejadian stunting, namun sebagian besar responden yang tidak memperoleh IMD mengalami stunting. Dengan demikian, pemberian IMD diidentifikasi sebagai faktor pemberian nutrisi yang berhubungan dengan kejadian stunting pada balita di Indonesia dan negara berkembang.

\section{Pemberian ASI Eksklusif}

ASI merupakan makanan ideal yang mengandung asupan protein, membantu mempertahankan pertumbuhan dan memenuhi kebutuhan bayi, serta memberikan perlindungan terhadap infeksi gastrointestinal yang dapat menyebabkan malnutrisi kronis (Koletzko, 2015). Pemberian ASI sebaiknya dimulai dari sejak lahir sampai usia 6 bulan. Hal ini didukung oleh penelitian Islam et al., (2018) India yang menunjukkan pemberian ASI eksklusif perlu ditingkatkan pada anak-anak, karena anak dapat mengalami peningkatan stunting sebanyak $24 \%$ pada usia 24 bulan yang dimulai sejak dilahirkan.

Hasil review juga mengidentifikasi 5 penelitian yang menunjukkan pemberian ASI Eksklusif berhubungan dengan stunting pada balita di Indonesia dan Negara Berkembang. Julianti (2020) di Indonesia menunjukkan terdapat hubungan signifikan pemberian ASI Eksklusif dengan kejadian stunting $(\mathrm{p}=0.001, \mathrm{OR}=2.28)$ yang artinya anak yang diberikan ASI Eksklusif memiliki 2,28 kali kemungkinan untuk tidak mengalami stunting. Demikian pula, Dewi (2015), Lailatul \& Ni'mah., (2015), Nugroho, (2016), dengan OR=3,7. Begitupun, Pandey \& Singh (2016) di Distrik India Tengah menunjukkan tingginya kejadian malnutrisi terkait pemberian asi eksklusif dengan OR (2,50-6,53). Hasil review ini juga mengidentifikasi tiga penelitian yang tidak mendukung hasil penelitian sebelumnya (Ahmad et al., 2018; Komaruddin et al., 2019; Fekadu et al., 2015).

Perbedaan hasil penelitian terkait pemberian ASI eksklusif dengan kejadian stunting dikarenakan pada penelitian Komaruddin et al., (2019) sampel penelitian yang diberikan ASI eksklusif memiliki jumlah sampel kecil, meskipun pada hasil penelitian ini tidak ada kaitan dengan kejadia stunting, namun pada penelitian ini ditemukan bukti bahwa menyusui dikaitkan dengan penambahan berat badan dan rendahnya morbiditas stunting pada anak dan memiliki peran dalam pencegahan malnutrisi. Begitupun, Ahmad et al., (2018) yang menunjukkan bahwa anak yang diberikan ASI eksklusif mengalami stunting sebanyak 67 (28\%) anak dan anak yang tidak diberikan ASI eksklusif sebanyak $42(27,6 \%)$ anak, meskipun 
jumlah anak yang diberi ASI eksklusif lebih banyak yang mengalami stunting namun secara presentasi hanya terdapat perbedaan $0,4 \%$ pada anak stunting yang diberikan ASI eksklusif dan tidak eksklusif.

Hasil review ini juga mengidentifikasi hubungan antara frekuensi menyusui dengan kejadian stunting pada balita di Indonesia dan Negara Berkembang. Penelitian Terati et al., (2018) di Indonesia menemukan ada hubungan antara frekuensi menyusui dengan stunting $(p=0,002)$. Demikian pula, Tian et al., (2019) di Distrik Changsha China menemukan terhentinya pemberian ASI eksklusif setelah 3 bulan pemberian dan pemberian ASI eksklusif selama 3 bulan dan dilanjutkan pemberian susu formula dan makan pada memiliki tingkat kejadian stunting yang tinggi. Hal ini dikarenakan, pada saat usia 0-6 bulan ASI mampu memenuhi kebutuhan asupan gizi bayi. Sehingga, pemberian susu formula di usia 3 bulan akan mengurangi perlindungan yang didapat dari ASI eksklusif dan seluruh manfaat ASI yang telah diperoleh sebelumnya.

Cetthakrikul et al., (2018) di Thailand menunjukkan, anak yang diberikan ASI eksklusif berkepanjangan yakni lebih dari 12 bulan pada keluarga miskin menjadi penyebab terjadinya stunting. Penelitian dilakukan pada komunitas keluarga miskin, dimana keluarga memiliki keterbatasan perekonomian, sehingga ibu kesulitan memberikan nutrisi yang sesuai kebutuhan anak. Oleh sebab itu, ibu hanya memberikan ASI saja selama 12 bulan. Sedangkan, ASI yang diberikan ibu juga kemungkinan tidak memiliki asupan gizi yang cukup. Pemberian ASI hanya mampu memenuhi kebutuhan asupan gizi anak sampai usia 6 bulan. Sedangkan setelah memasuki usia 6 bulan lebih, ASI tidak lagi dapat memenuhi kebutuhan gizi anak, sehingga perlu diberikan makanan tambahan, dengan tetap diberikan ASI hingga usia 24 bulan atau lebih. Oleh sebab itu, pemberian ASI yang berkepanjangan dapat menyebabkan anak mengalami stunting.

Hal ini sesuai dengan Julianti (2020) di Indonesia yang menunjukkan, anak yang tidak diberi ASI Eksklusif memiliki 40,9\% risiko stunting. Begitupun, Mihrete (2018) di wiliyah Somali State, Ethiopia menunjukkan frekuensi menyusui pada bayi dapat mengurangi risiko bayi stunting. Sehingga, pemberian ASI eksklusif diidentifikasi sebagai salah satu faktor pemberian nutrisi yang berhubungan dengan kejadian stunting. Untuk itu, sebagai upaya pencegahan dan penanganan kondisi tersebut, penting untuk memperhatikan pemberian ASI sesuai dengan indikasi eksklusif.

\section{Pemberian MP-ASI}

Berdasarkan hasil review, pemberian ASI hanya dapat memenuhi kebutuhan gizi bayi sampai usia 6 bulan, sehingga pada bayi usia 6 bulan-24 bulan perlu dilakukan pemberian Makanan Pendamping ASI untuk mencukupi kebutuhan gizi anak. Hasil penelitian Bukusuba et al., (2017) di Uganda menunjukkan praktik pemberian makan pada bayi dan anak-anak atau infant and young child feeding (IYCF) yang kurang tepat $(\mathrm{p}<0.05)$ merupakan kontributor utama terhambatnya pertumbuhan di Distrik Buhweju, Uganda. Begitupun, Abeway et al., (2018) di Ethiopia Utara menunjukkan Inisiasi pemberian Makanan Pendamping ASI yang salah merupakan determinan faktor stunting pada anak usia 6-9 bulan (OR: 2,4) artinya anak yang diberikan MP-ASI sebelum usia 6 bulan memilik 2,4 kali kemungkinan mengalami stunting dibanding anak yang diberikan MP-ASI tepat waktu.

Berdasarkan penelitian Nugroho (2016) di Indonesia, menunjukkan Makanan Pendamping ASI dini merupakan faktor yang berhubungan dengan stunting ( $\mathrm{OR}=3,7$; $\mathrm{p}=0,008$ ). Demikian pula, Fekadu et al., (2015) di Ethopia mengemukakan pengenalan Makanan Pendamping ASI terlalu dini merupakan faktor prediktor kejadian stunting. Begitupun, Aridiyah (2015) di Wilayah Perkotaan dan Pedesaan Indonesia menunjukkan umur pertama pemberian Makanan Pendamping ASI yang berhunungan dengan kejadian stunting ( $p>0,05)$. Sama seperti, Khasanah et al., (2016) di Indonesia menunjukkan waktu pertama kali pemberian makanan pendamping ASI berhubungan signifikan dengan kejadian stunting $(\mathrm{OR}=2,867)$. Demikian pula, Mihrete (2018) di wiliyah Somali State, Ethiopia 
menunjukkan pengenalan Makanan Pendamping ASI sebelum 6 bulan signifikan terhadap stunting.

Pemberian makanan penamping ASI terlalu dini dapat menyebakan anak tidak memperoleh manfaat ASI eksklusif. Pemberian makanan pendamping ASI terlalu dini yakni pemberian makan sebelum usia anak lebih dari 6 bulan dapat menyebabkan anak cepat merasa kenyang, namun kebutuhan asupan gizi yang seharusnya belum terpenuhi. Selain itu, anak akan malas untuk menyusu dan menyebabkan anak tidak memperoleh ASI. Padahal, ASI memiliki komposisi gizi yang lengkap, sehingga dapat membantu bayi terhindar dari malnutrisi, merangsang kecerdasan emosional dan fungsi otak maskimal (Astutik, 2014; Maryunani, 2012).

Hasil review ini juga mengidentifikasi, pemberian Makanan Pendamping ASI yang tidak memperhatikan frekuensi, tekstur, dan waktu pemberian makanan berhubungan dengan kejadian stunting pada balita di Indonesia dan Negara Berkembang. Hal ini terlihat dari penelitian Nurdin et al., (2019) di Indonesia yang menunjukkan pemberian Makanan Pendamping ASI yang tidak memperhatikan frekuensi memiliki OR=3,90. Demikian pula, Pandey \& Singh (2016) di Distrik India Tengah yang menunjukkan tingginya kejadian malnutrisi akibat kurangnya pemberian makan semi padat, dan pemberian Makanan Pendamping yang jarang dengan $\mathrm{OR}=3,01-8,39$. Demikian pula, Ahmad et al., (2018) di Indonesia menunjukkan Pemberian makanan tambahan yang tepat waktu dan beragam berkaitan dengan kejadian stunting $(\mathrm{P}=0,015)$.

Selain itu, hasil review juga mengidentifikasi pemberian makanan pendamping ASI yang tidak memperhatikan variasi/keragaman makanan berhubungan dengan kejadian stunting pada balita di Indonesia dan Negara Berkembang. Hal ini terlihat dari hasil penelitian Balalian et al., (2017) di Armenia, yang menunjukkan Anak usia 6-24 bulan yang diberikan Makanan Pendamping yang beragam memiliki peluang $72 \%$ lebih rendah untuk menjadi stunting $(p<0,05)$. Demikian pula, Nurdin et al., (2019) di Indonesia menunjukkan pemberian nutrisi dengan memperhatikan variasi Makanan Pendamping ASI berhubungan dengan kejadian stunting dengan $\mathrm{OR}=3,260$. BegitupunFekadu et al., (2015) di Ethopia dengan $\mathrm{OR}=0.25$.

Pada usia 6-12 bulan anak dapat diberikan makanan lembek dengan frekuensi $2 x$ sehari 2x selingan. Pada 1-3 tahun anak sudah dapat diberikan makanan keluarga sebanyak $1^{1 / 2}$ piring nasi pengganti, 2-3 potong lauk hewani, 1-2 potong lauk nabati, 1/2 mangkuk sayur, 2-3 potong buah-buahan, 1 gelas susu sebanyak $3 \times$ sehari. Jika tidak memperoleh nutrisi dengan tepat, anak dapat mengalami kekurangan asupan nutrisi dan menyebabkan asupan energi yang dibutuhkan untuk metabolisme tubuh tidak tercukupi. Sehingga, secara fisiologis tubuh akan melakukan penyesuaian untuk metabolisme berkelanjutan dengan membongkar simpanan zat gizi, lemak dan otot dalam tubuh guna memastikan organ vital mendapatkan asupan energi yang cukup dan mengakibatkan simpanan nutrisi yang akan digunakan untuk pertumbuhan terpakai untuk kebutuhan asupan energi organ vital (Briend et al., 2015; Black et al., 2013). Dengan demikian, anak akan membutuhkan makanan tambahan guna mencegah kekurangan gizi kronis, yang jika dibiarkan dapat menyababkan stunting.

Hasil review ini mengidentifikasi bahwa pemberian Makanan Pendamping ASI yang tidak memperhatikan frekuensi, tekstur, waktu pemberian, dan keragaman dapat menyebabkan kejadian stunting pada balita. Untuk itu, sebagai pencegahan dan penanganan stunting, makanan tambahan yang akan diberikan harus mampu menggantikan fungsi ASI yang berkurang dan sesuai kebutuhan gizi anak dengan memperhatikan frekuensi, tekstur dan waktu pemberian, serta keragaman makanan pendamping.

\section{SIMPULAN}

Hasil review mengidentifikasi faktor-faktor pemberian nutrisi pada masa golden age dengan kejadian stunting pada balita di Indonesia dan Negara Berkembang meliputi: status gizi ibu hamil (peningkatan asupan nutrisi, energi dan protein selama kehamilan), faktor 
pemberian Inisiasi Menyusui Dini, faktor pemberian ASI eksklusif (pemberian ASI non eksklusif dan frekuensi menyusui), faktor pemberian Makanan Pendamping ASI (frekuensi, tekstur, waktu pemberian, dan keragaman).

\section{UCAPAN TERIMA KASIH}

Terimakasih kepada semua pihak yang telah berkontribusi secara langsung maupun tidak langsung dalam sistematik review ini.

\section{DAFTAR PUSTAKA}

Abeway, S., Gebremichael, B., Murugan, R., Assefa, M., \& Adinew, Y. M. (2018). Stunting and its determinants among children aged 6-59 Months in Northern Ethiopia: A crosssectional study. Journal of Nutrition and Metabolism, 2018. https://doi.org/10.1155/2018/1078480

Ahmad, A., Madanijah, S., Dwiriani, C. M., \& Kolopaking, R. (2018). Complementary feeding practices and nutritional status of children 6-23 months old: Formative study in Aceh, Indonesia. Nutrition Research and Practice, 12(6), 512-520. https://doi.org/10.4162/nrp.2018.12.6.512

Alfarisi, R., Nurmalasari, Y., Nabilla, S., Dokter, P. P., Kedokteran, F., Malahayati, U., Dokter, P. P., Kedokteran, F., Malahayati, U., Dokter, P. P., Kedokteran, F., \& Malahayati, U. (2019). Status Gizi Ibu Hamil Dapat Menyebabkan. 5(3), 271-278.

Almatsier, S., Soetardjo, Susirah., \& Soekatri, M. (2011). Gizi Seimbang dalam Daur Kehidupan. Gramedia.

Angelina, C. F., Perdana, A. P., \& H. (2016). Faktor Kejadian Stunting Balita Berusia 6-23 Bulan di Provinsi Lampung. Jurnal Dunia Kesmas, 73.

Apriluana, G., \& Fikawati, S. (2018). Analisis Faktor-Faktor Risiko terhadap Kejadian Stunting pada Balita (0-59 Bulan) di Negara Berkembang dan Asia Tenggara. Media Penelitian dan Pengembangan Kesehatan, 28(4), 247-256. https://doi.org/10.22435/mpk.v28i4.472

Aridiyah. (2013). Faktor-faktor yang Mempengaruhi Kejadian Stunting pada Anak Balita di Wilayah Pedesaan dan Perkotaan (The Factors Affecting Stunting on Toddlers in Rural and Urban Areas) | Pustaka Kesehatan. 3(1).

Astutik, R. . (2014). Payudara dan Laktasi. Salemba Medika.

Balalian, A. A., Simonyan, H., Hekimian, K., Deckelbaum, R. J., \& Sargsyan, A. (2017). Prevalence and determinants of stunting in a conflict-ridden border region in Armenia - A cross-sectional study. BMC Nutrition, 3(1), 1-13. https://doi.org/10.1186/s40795017-0204-9

Bappenas. (2018). Intervensi Penurunan Stunting. In Pedoman Pelaksanaan Intervensi Penurunan Stunting Terintegrasi di Kabupaten/Kota (Nomor November, hal. 1-59).

Batiro, B., Demissie, T., Halala, Y., \& Anjulo, A. A. (2017). Determinants of stunting among children aged 6-59 months at Kindo Didaye woreda, Wolaita Zone, Southern Ethiopia: Unmatched case control study. 1-15.

Black, R. E., Victora, C. G., Walker, S. P., Bhutta, Z. A., Christian, P., de Onis, M., Ezzati, M., Grantham-McGregor, S., Katz, J., Martorell, R., \& Uauy, R. (2013). Maternal and child undernutrition and overweight in low-income and middle-income countries. The Lancet, 382(9890), 427-451. https:/ / doi.org/10.1016/S0140-6736(13)60937-X

Briend, A., Khara, T., \& Dolan, C. (2015). Wasting and stunting-similarities and differences: Policy and programmatic implications. Food and Nutrition Bulletin, 36(1), S15-S23. https://doi.org/10.1177/15648265150361S103

Bukusuba, J., Kaaya, A. N., \& Atukwase, A. (2017). Risk factors for stunted growth among children aged 6-59 months in rural Uganda. International Journal of Nutrition, 2(3), 1-13. https:// doi.org/10.14302/issn.2379-7835.ijn-16-1408

Cetthakrikul, N., Topothai, C., Suphanchaimat, R., Tisayaticom, K., Limwattananon, S., \& Tangcharoensathien, V. (2018). Erty. BMC Pediatrics, 18(1), 1-9. 
Damayanti, R. A., Muniroh, L., \& F. (2016). Perbedaan Tingkat Kecukupan Zat Gizi dan Riwayat Pemberian Asi Eksklusif pada Balita Stunting dan Non stunting (II (1)).

De Onis, M., Blössner, M., \& Borghi, E. (2012). Prevalence and trends of stunting among preschool children, 1990-2020. Public Health Nutrition, 15(1), 142-148. https://doi.org/10.1017/S1368980011001315

Dewey, K. G., \& Begum, K. (2011). Long-term consequences of stunting in early life. Maternal and Child Nutrition, 7(SUPPL. 3), 5-18. https://doi.org/10.1111/j.17408709.2011.00349.x

Dewi, D. P. (2015). Status Stunting Kaitannya Dengan Pemberian Asi. Jurnal Medika Respatiespati, 10, 60-66.

Dhaded, S. M., Hambidge, K. M., Ali, S. A., Somannavar, M., Saleem, S., Pasha, O., Khan, U., Herekar, V., Vernekar, S., Yogesh Kumar, S., Westcott, J. E., Thorsten, V. R., Sridhar, A., Das, A., McClure, E., Derman, R. J., Goldenberg, R. L., Koso-Thomas, M., Goudar, S. S., \& Krebs, N. F. (2020). Preconception nutrition intervention improved birth length and reduced stunting and wasting in newborns in South Asia: The Women First $\begin{array}{lllll}\text { Randomized Controlled Trial. PLOS ONE, 15(1), 15. } & \text { 1- }\end{array}$ https:// doi.org/10.1371/journal.pone.0218960

Fekadu, Y., Mesfin, A., Haile, D., \& Stoecker, B. J. (2015). Factors associated with nutritional status of infants and young children in Somali Region, Ethiopia: A cross- sectional study Global health. BMC Public Health, 15(1), 1-10. https://doi.org/10.1186/s12889015-2190-7

Fitri, L., \& Ernita. (2019). Hubungan Pemberian ASI Eksklusif dan MP ASI Dini dengan Kejadian Stunting Pada Balita. Jurnal Ilmu Kebidanan, 8(1), 19-24.

Helmyati, S., Atmaka, D. R., Wisnusanti, S. U., dan Wigati, M. (2019). Stunting Permasalahan dan Penanganannya. Gajah Mada University Press.

Hossain, M., Choudhury, N., Abdullah, K. A. B., Mondal, P., Jackson, A. A., Walson, J., \& Ahmed, T. (2017). Evidence-based approaches to childhood stunting in low and middle income countries: A systematic review. Archives of Disease in Childhood, 102(10), 903909. https://doi.org/10.1136/archdischild-2016-311050

IDAI. (2015). Rekomendasi Praktik Pemberian Makan Berbasis Bukti pada Bayi dan Batita di Indonesia untuk Mencegah Malnutrisi. Unit Kerja Koordinasi Nutrisi dan Penyakit Metabolik, Ikatan Dokter Anak Indonesia.

Indah Nurdin, S. S., Octaviani Katili, D. N., \& Ahmad, Z. F. (2019). Faktor ibu, pola asuh anak, dan MPASI terhadap kejadian stunting di kabupaten Gorontalo. Jurnal Riset Kebidanan Indonesia, 3(2), 74-81. https:// doi.org/10.32536/jrki.v3i2.57

Islam, M. M., Sanin, K. I., Mahfuz, M., Ahmed, A. M. S., \& Mondal, D. (2018). Faktor risiko stunting pada anak-anak yang tinggal di daerah kumuh perkotaan dari Bangladesh: Temuan dari penelitian kohort prospektif. 0, 1-13.

Java, W., \& Tenggara, E. N. (2014). Faktor risiko stunting pada anak usia 0-23 bulan di provinsi bali, jawa barat, dan nusa tenggara timur. Jurnal Gizi dan Pangan, 9(2), 125132. https:// doi.org/10.25182/jgp.2014.9.2.\%p

Julianti, E. (2020). Faktor Penentu Pengerdilan pada Anak Berumur 12-59 Bulan. 10(1), 36-45.

Kemenkes RI. (2016). Situasi balita pendek. Pusat Data dan Informasi Kementerian Kesehatan RI.

Kemenkes RI. (2019). Kebijakan dan strategi penanggulangan stunting di indonesia. Germas, 2(2), 41-52.

Khasanah, D. P., Hadi, H., \& Paramashanti, B. A. (2016). Waktu pemberian makanan pendamping ASI (MP-ASI) berhubungan dengan kejadian stunting anak usia 6-23 bulan di Kecamatan Sedayu. Jurnal Gizi dan Dietetik Indonesia (Indonesian Journal of Nutrition and Dietetics), 4(2), 105. https://doi.org/10.21927/ijnd.2016.4(2).105-111

Kismul, H., Acharya, P., Mapatano, M. A., \& Hatløy, A. (2017). Determinants of childhood stunting in the Democratic Republic of Congo: Further analysis of Demographic and 
Health Survey 2013-14. In BMC Public Health (Vol. 18, Nomor 1, hal. 1-14). BMC Public Health. https:/ / doi.org/10.1186/s12889-017-4621-0

Koletzko, B. (2015). Supported by an unrestricted educational World Review of Nutrition and Berthold Koletzko Munich.

Komaruddin, W. N., Juffrie, M., Pusponegoro, H., Astuti, I., Patria, S. Y., \& Mardhiyah, D. (2019). Dietary Diversity and Stunting Among 6-23 Months Children:Community Cross-Sectional Study in East Jakarta. Malaysian Journal of Medical Research, 03(03), 1420. https://doi.org/10.31674/mjmr.2019.v03i03.003

Kristiyanasari, W. (2010). Gizi Ibu Hamil. Nuha Medika.

Kusuma, K. E., \& Nuryanto. (2013). Faktor Risiko Kejadian Stunting pada Anak Usia 2-3 Tahun. Journal of Nutrition College, 2(4), 523-530.

Lailatul, M., \& Ni'mah., C. (2015). Hubungan Tingkat Pendidikan, Tingkat Pengetahuan dan Pola Asuh Ibu dengan Wasting dan Stunting pada Balita Keluarga Miskin. Media Gizi Indonesia, 10(2015), 84-90. https:/ / doi.org/Vol. 10, No. 1 Januari-Juni 2015: hlm. 84-90 terdiri

Marmi. (2013). Gizi dalam Kesehatan Reproduksi. Pustaka Pelajar.

Maryunani, A. (2012). Inisiasi Menyusui Dini, Asi Eksklusif dan Manajemen Laktasi. Trans Info Media.

Mediani, H. S. (2020). Predictors of Stunting Among Children Under Five Year of Age in Indonesia: A Scoping Review. Global Journal of Health Science, 12(8), 83. https://doi.org/10.5539/gjhs.v12n8p83

Mihrete, Y. (2018). Assessment of Stunting, Wasting Rate and Associated Factors among Children 0-59 Months at Jigjiga Town in Somali Regional State, Ethiopia. Journal of Food, Nutrition and Population Health, 02(01), 0-4. https://doi.org/10.21767/25770586.100033

Millenium challenge count (MAC) Indonesia. (2013). Stunting dan Masa Depan Indonesia (hal. 2-5). Millenn Chall Acc-Indonesia.

Mufida, L., Widyaningsih, T. D., \& Maligan, J. M. (2015). Prinsip Dasar Makanan Pendamping Air Susu Ibu ( MP-ASI ) untuk Bayi 6 - 24 Bulan : Kajian Pustaka. Basic Principles of Complementary Feeding for Infant 6 - 24 Months: A Review. Jurnal Pangan dan Agroindustri, 3(4), 1646-1651.

Nelly SD Situmeang, Etti Sudaryati, \& Jumirah. (2020). Correlation of Parenting and Nutrient Intake with Stunting in Children 24-59 Months. Britain International of Exact Sciences (BIoEx) Journal, 2(1), 280-285. https://doi.org/10.33258/bioex.v2i1.147

Nugroho, A. (2016). Determinan Growth Failure (Stunting) pada Anak Umur 1 S/D 3 Tahun (Studi di Kecamatan Tanjungkarang Barat Kota Bandar Lampung). Jurnal Kesehatan, 7(3), 470. https://doi.org/10.26630/jk.v7i3.231

Pandey, P., \& Singh, S. K. (2016). Dietary determinant of severe acute malnutrition among infants: Evidence from a case controlled study at a Central Indian district. South East Asia Journal of Public Health, 6(1), 32-39. https:/ / doi.org/10.3329/seajph.v6i1.30342

Permadi, M. R., Hanim, D., Kusnandar, K., \& Indarto, D. (2017). Risiko Inisiasi Menyusu Dini dan Praktek ASI Eksklusif terhadap Kejadian Stunting pada Anak 6-24 Bulan. Penelitian Gizi dan Makanan (The Journal of Nutrition and Food Research), 39(1), 9-14. https://doi.org/10.22435/pgm.v39i1.5965.9-14

Prabandari, Y., Hanim, D., AR, R. C., \& Indarto, D. (2017). Hubungan Kurang Energi Kronik Dan Anemia Pada Ibu Hamil Dengan Status Gizi Bayi Usia 6-12 Bulan Di Kabupaten Boyolali (Correlation Chronic Energy Deficiency and Anemia During Pregnancy With Nutritional Status of Infant 6 - 12 Months in Boyolali Regency). Penelitian Gizi dan Makanan (The Journal of Nutrition and Food Research), 39(1). https://doi.org/10.22435/pgm.v39i1.5964.1-8

Schmidt. C., W. (2014). Beyond Malnutrition: The Role of Sanitation in Stunted Growth. Environ. Environ Health Perspect. 
Sentana, L. F. Hrp, J. R., dan Hasan, Z. (2018). Faktor-Faktor Yang Berhubungan Dengan Kejadian Stunting Pada Anak Usia 12-24 Bulan Di Kelurahan Kampung Tengah Kecamatan Sukajadi Pekanbaru. Jurnal Ibu dan Anak, 6(November), 89-95.

Som, S. V., Prak, S., Laillou, A., Gauthier, L., Berger, J., Poirot, E., \& Wieringa, F. T. (2018). Diets and feeding practices during the first 1000 days window in the phnom penh and north eastern districts of Cambodia. Nutrients, 10(4). https:// doi.org/10.3390/nu10040500

Terati, Yuniarti, H., \& Susanto, E. (2018). Effects of diet and breastfeeding duration on the stunting status of children under 5 years of age at maternal and child health centers of the Palembang regional office of health. Pakistan Journal of Nutrition, 17(2), 51-56. https:// doi.org/10.3923/pjn.2018.51.56

Tian, Q., Gao, X., Sha, T., Chen, C., Li, L., He, Q., Cheng, G., Wu, X., Yang, F., \& Yan, Y. (2019). Effect of feeding patterns on growth and nutritional status of children aged 0-24 months: A Chinese cohort study. PLoS ONE, 14(11), 1-13. https://doi.org/10.1371/journal.pone.0224968

Tim Nasional Percepatan Penanggulangan Kemiskinan. (n.d.). 100 Kabupaten/Kota Prioritas untuk Intervensi Anak Kerdil (Stunting). 1.

Trihono, Atmarita, Tjandrarini, D. H., Tejayanti, T., \& Nurlinawati, I. (2015). Pendek (stunting) di Indonesia, Masalah dan Solusinya. Lembaga Penerbit Balitbangkes.

UNDP. (2016). UNDP Support To the Implementationof Sustainable Development Goal 5. United Nations Development Programme.

UNICEF. (2013). Ringkasan Kajian Gizi Ibu dan Anak.

W. Ferial, E. (2012). Hubungan antara Status Gizi Ibu berdasarkan Ukuran Lingkar Lengan Atas (LIA) dengan Berat Badan Lahir Bayi di RSUD Daya Kota Makassar. 2(3), 11-22.

WHO. (2014). Child Growth Standards: Methods and Development.

WHO. (2018). Reducing Stunting (hal. 1-25). https://www.who.int/nutrition/publications/severemalnutrition/reducingstunting-children-equity/en/ (diakses pada tanggal 31 Maret 2020) 